ХУДОЖНЬО-МЕНТАЛЬНИЙ ДОСВІД У КОМПЕТЕНТНІСНІЙ ПАРАДИГМІ МАЙБУТНЬОГО ВЧИТЕЛЯ ХОРЕОГРАФІЇ

\title{
ART-MENTAL EXPERIENCE IN THE COMPETENCE PARADIGM OF THE FUTURE CHOREOGRAPHY TEACHER
}

у статmі зазначено, що пріоритетним напрямом розвитку вищої педагогічної освіти останнім часом стало підвищення ї̈ якості. Мета педагогічної освіти полягає у формуванні ключових компетентностей учителів різних спеціалізацій. Доведено, що підвищення якості хореограсрічної освіти безпосередньо залежить від компетент ного фрахівця-хореографра. Серед ключових компетентностей, необхідних майбутнім учителям хореографрії для здійснення професійної діяльності, у статmі виокремлено художньо-ментальний досвід як ореномен упідготовці майбутніх учителів хореографрії, що дозволяє сформувати у свідомості студентів художню модель світу в особливих знаках і формах, котрі впливають на ціннісні орієнтації, а також на поведінку та ставлення до навколишнього середовища. Meта художньо-ментального досвіду полягає у фрормуванні в майбутнього вчителя хореографрії фрахової художньої ментальності, яка фуункціонує та проявляється в художньо-комунікативних і творчо-виконавських процесах (сприйняття, відтворення, інтерпретація), що в результаті формує художньо-ментальний досвід особистості. Художньо-ментальний досвід $є$ чинником підвищення якості освіти майбутніх хореографрів, оскільки впливає на формування ментальності особистості. Визначальними в цьому процесі $є$ творча самостійність, яка характеризується здатністю образно мислити, застосовувати раніше отримані знання на практиці, знаходити нестандартні рішення, змінювати ракурс погляду, бачити альтернативу тощо; толерантність, емпатійність, духовність (прагнення вплинути на духовний світ інших через мистецтво); виконавська й емоційнообразна мобільність, що проявляється у форомі швидких емоційних реакцій на різні художньо-образні явища. Метою статmі $\epsilon$ висвітлення сутності художньо-ментального досвіду майбутніх учителів хореограсріі в компетентнісній парадигмі. Для вирішення поставленої мети використано теоретичні методи, а саме: аналіз педагогічної літератури для уточнення сутності понять «менталітет», «ментальність», «художня ментальність», «художньо-ментальний досвід», синтез, порівняння, систематизація, теоретичне узагальнення даних для з'ясування особливостей художньо-ментального досвіду. Серед перспективних напрямів подальших розвідок $є$ порівняльна характеристика зазначеної проблематики в Україні й інших прогресивних країнах світу.
Ключові слова: компетентність, учитель, хореографр, підготовка, освіта, досвід, художній, ментальність.

The article is determined that improving the quality of higher education has recently become a priority. The purpose of education is to form the key competences in different majority teachers. It is proved that the improvement of choreographic education quality depends directly on the competent of specialist-choreographer. Among the key competencies required for future choreography teachers to pursue a professional activity, the article is highlighted the artistic and mental experience as a phenomenon in the future choreography teachers training. It is allowed to create an artistic model of the world in the students' minds using special signs and forms that affect the value orientations, also behavior and attitude to the environment. The purpose of the artistic-mental experience is to form the professional artistic mentality in future choreography teacher, which functions and express in artistic-communicative and creative-performing processes (perception, reproduction, interpretation), which as a result forms the person's artistic-mental experience. The artistic and mental experience is a factor of improving the quality of future choreographers' education because it influences the formation of the personal mentality. The creative independence is defined issue in this process, which is characterized by the ability to think imaginatively, to apply previously acquired knowledge in practice, to find non-standard solutions, to change the perspective, to see an alternative, etc.; tolerance, empathy, spirituality (desire to influence the spiritual world of other people by art); performing and emotional-imaginative mobility, expressed in the form of rapid emotional reactions to various artistic and imaginative phenomena. The purpose of the article is to highlight the essence of the artistic and mental experience of future teachers of choreography in a competence paradigm. The theoretical methods used to solve this purpose are the following: analysis of pedagogical literature to clarify the essence of the concepts "mentality", "artistic mentality", "artistic and mental experience", synthesis, comparison, systematization, the theoretical generalization of data for understanding the features of artistic and mental experience. The promising directions of further study are the following: the comparative characteristic of these problems in Ukraine and other progressive countries of the world.

Key words: competence, teacher, choreographer, training, education, experience, artistic, mentality.
Постановка проблеми у загальному вигляді та її зв'язок з важливими науковими чи практичними завданнями. XXI сторіччя знаменується постійними реорормами в освітньому просторі. Інноваційні зміни залежать насамперед від учителя, компетентного і вмотивованого до змін професіонала, його творчого потенціалу, готовності до безперервної освіти, що, звичайно, вимагає вдосконалення його підготовки в стінах закладів вищої педагогічної освіти.

У рефрормуванні системи вищої педагогічної освіти в Україні значне місце посідає компетентнісна парадигма, зумовлена глобалізацією освіти. Вона сприяє визначенню не лише мети, але й 
змісту освітніх програм, орієнтує шлях досягнення результатів роботи як закладу освіти в цілому, так і кожного студента зокрема. В основу компетентнісного підходу покладено не тільки спектр необхідних знань, умінь і навичок, а й сам процес і результат творчої діяльності педагога, інтегрований покажчик особистісно-діяльнісної сутності вчителя.

Аналіз останніх досліджень і публікацій. Питанням компетентнісного підходу в підготовці майбутніх учителів дисциплін художньо-естетичного циклу свої дослідження присвятили Т. Акатова, М. Безуглий, В. Вершловський, Б. Віт, Б. Гершунський, Д. Денгерінк, Лю Цяньцянь, Н. Сметаннікова, М. Снок, А. Старченко та інші. Стратегіями підготовки майбутніх учителів хореографії цікавилися О. Авраменко, О. Пархоменко, О. Реброва, Т. Сердюк, І. Степанюк та інші. Проблемами підготовки фрахівців, ії ефективності та результативності займаються Г. Галасц, Т. Браже, С. Кульневич, А. Хуторський та інші.

Виділення невирішених раніше частин загальної проблеми. Загалом питаннями фрормування професійних компетентностей майбутніх учителів займаються вчені досить жваво, проте художньо-ментальний досвід майбутніх учителів хореографії залишається поза увагою дослідників.

Мета статті - висвітлити сутність художньоментального досвіду майбутніх учителів хореографії в компетентнісній парадигмі.

Виклад основного матеріалу дослідження. Термін «хореографрія» (від грец. «сhoreia» танець i «grapho» - пишу), вжитий уперше Р. Фейе (Французька Академія танцю) у 1700 році, використовується сьогодні у трьох значеннях й означає мистецтво танцю, мистецтво створення танців і танцювальних спектаклів, запис танцю за допомогою системи умовних знаків.

О. Авраменко дає визначення хореографрічному мистецтву як «сфері духовної культури $з$ її унікальними можливостями впливу на особистість, яка має розглядатися не тільки як джерело розвитку спеціальних художньо-творчих хореографрічних здібностей майбутнього фрахівця, а також як універсальний засіб формування його загальнокультурних ціннісних орієнтацій, духовно-творчого потенціалу. Вектор підготовки майбутніх хореографрів до профресійної діяльності спрямовується в площину усвідомлення значущості мистецькохореографрічної діяльності, їх особистісного зростання та прагнення усіляко сприяти творчому розвитку кожної дитини, як унікальної та неповторної, у процесі хореографрічної діяльності в шкільних і позашкільних закладах освіти» [5].

Хореографрічна діяльність є синтезом фрізичного та естетичного розвитку особистості, позитивно впливає на її соціалізацію, становлення її світоглядної культури, фрормування здатності до саморегуляції та самовдосконалення, має здоров'я-зберігаючий потенціал, задовольняє художньо-творчі потреби, сприяє вихованню національної свідомості, ментальності тощо.

3 огляду на це підготовка вчителя хореографрії $€$ актуальним і затребуваним процесом, чинником фрормування національної та загальнолюдської свідомості. На думку І. Степанюк, хореографічна підготовка $€$ відносно самостійною керованою системою цілеспрямованого духовного розвитку майбутніх фрахівців за допомогою засвоєння знань і фрормування вмінь і навичок; ефективним засобом розвитку їхньої світоглядної культури, фрормування здатності до вдосконалення творчих здібностей засобами хореографії [8].

О. Пархоменко визначає підготовку майбутніх хореографрів до професійної діяльності як «інтегральне, цілісне утворення особистості фрахівця, яке включає в себе готовність до здійснення професійної діяльності на основі спеціальних хореографрічних знань, умінь, навичок і профресійно-особистісних якостей» [4]. Автор стверджує, що зміст професійної хореографрічної освіти зводиться не тільки до наукових знань, але й включає засвоєння емоційно-образного світу мистецтва, історичних традицій і сучасних інновацій.

На думку О. Авраменка, у процесі фрахової підготовки майбутні хореографи мають оволодіти такими компетентностями:

- володіння базовими загальними знаннями, a саме: історія, теорія та практика хореографічного мистецтва, методика виконання та викладання різних видів хореографії (класичний, сучасний, народно-сценічний танець тощо);

- здатність використовувати основи теорії та методології хореографрії в інноваційній професійній діяльності, проектувати й здійснювати освітній процес хореографрічного навчання з урахуванням соціокультурної ситуації та рівня розвитку хореографрічних здібностей учнівського колективу в системі освіти в реальному та віртуальному середовищі;

- обізнаність із сучасними напрямами хореографрічного мистецтва, критичне ставлення до модних танцювальних течій;

- уміння створювати танцювальний репертуар різного рівня складності відповідно до соціальних та культурних потреб суспільства;

- здатність до саморозвитку на основі ресрлексії результатів своєї професійної діяльності, здатність користуватися освітньо-комунікаційними технологіями, знаходити та використовувати інорормацію з різних джерел (електронних, письмових, архівних та усних) згідно з поставленим завданням [1, с. 14]

О. Пархоменко зазначає, що професійнадіяльність майбутніх хореографрів має свою специфріку залежно від галузі творчої реалізації. Вона реалізується у конструктивній, освітньо-виховній, інфрормаційно-просвітницькій, комунікативній, організаторській, соціально- 
психологічній і дослідницькій роботі. Дослідник наголошує на важливих складниках фрормування балетмейстерських умінь майбутніх хореографрів, a саме: педагогічні переконання, майстерність, професіоналізм, творчість, культура, здібності, самосвідомість та спрямованість [4].

У своїх дослідженнях Т. Сердюк зосереджує увагу на фрормуванні художньо-естетичного досвіду майбутніх хореографрів у процесі їхньої професійної підготовки у ЗВО. Дослідниця конкретизує сутність, зміст і компонентну структуру художньо-естетичного досвіду студентів-хореографрів, яка полягає у взаємодії когнітивного, аксіологічного та праксеологічного складників у процесі художньо-естетичної діяльності особистості [7].

Лю Цяньцянь у вчителів мистецьких дисциплін виокремлює культурну, крос-культурну та мистецьку компетентності [10]. О. Щоколова наголошує на оволодінні вчителями хореографрії духовною компетентністю як гармонійним поєднанням пізнавального, морального й естетичного, котре виражається через істину, добро та красу [11], а також «художньоментальним досвідом» [10, с. 62-63], який дозволяє сорормувати у свідомості студентів художню модель світу в особливих знаках і формах, котрі впливають на ціннісні орієнтації, а також на поведінку і ставлення до навколишнього середовища.

Концептуальною основою набуття художньо-ментального досвіду стає підвищення якості фрахової освіти від художньої грамотності (через освіченість, компетентність, культуру) до фрахової художньої ментальності. Стереоскопічним вектором художньої ментальності особистості є історично розвинені типи художньої свідомості: від міфрологічного, релігійного, фрольклорного до ціннісного, художньо-світоглядного та художньо-наукового. Зазначені типи в сучасному освітньому процесі стосовно ментальності зумовлюють вибір змістових ліній для формування художньо-ментального досвіду, домінантою якого є осягнення, опанування художніх цінностей минулого, їх екстраполяція на сучасність та проективна стратегія у майбутньому.

Термін «ментальність» (від лат. - розумовий, духовний) означає сукупність переконань, поглядів і умонастроїв, утілених у традиціях, звичаях і ритуалах, характерних для певної спільноти, що відображує особливості психічного складу й способу мислення ії членів та відрізняє їх від інших спільностей. На думку М. Бетільмерзаєвої, ментальність у культурологічному аспекті можна вважати генетикою культури, оскільки виявлення ії природи неможливе поза аналізом свідомості, виявлення культурних френоменів (базових структур), що відповідають за збереження та передачу соціального досвіду людини [2, с. 9].

Художня ментальність - це феномен, який синтезує уявлення про картину світу, тип мислення з художньо-семантичними ресурсами мистецтва в творчих процесах на основі культурно-історичних, етно-національних, освітньо-професійних мистецьких фракторів, які спрямовують фрормування індивідуального художнього досвіду та емоційно-духовної налаштованості особистості відповідно до художніх цінностей народу, має власні модуси - атрибутивні та процесуальні властивості, через які вона виявляє свою сутність [5].

У підготовці майбутніх учителів мистецьких дисциплін художня ментальність як властивий мистецтву феномен фрункціонує та проявляється в художньо-комунікативних і творчо-виконавських процесах (сприйняття, відтворення, інтерпретація), що в результаті фрормує художньо-ментальний досвід особистості.

Ментальність як сукупність переконань потрібно розрізняти від поняття менталітету. Менталітет зумовлює конкретні вчинки людей, їхнє ставлення до різних проявів життя суспільства, у ньому втілюються глибинні основи світосприймання, світогляду й поведінки. Відповідно, менталітет представлений у дослідженнях як «здатність акумулювати і передавати національні культурні цінності та етнічні стереотипи», адже представник будь-якого етносу мислить, переживає, спілкується й діє згідно з національним менталітетом й етнокультурним середовищем [9].

За переконанням Б. Гершунського, у структурному ланцюжку результативності освіти - «грамотність» - «освіченість» - «профресійна компетентність» - «культура» - «менталітет» - саме менталітет посідає ієрархічно вищий щабель, зумовлюючи зміст усіх попередніх [3].

О. Реброва зазначає, що художньо-ментальний досвід є чинником підвищення якості освіти майбутніх хореографів, оскільки впливає на формування ментальності особистості. Визначальними в цьому процесі, на думку авторки, є творча самостійність, яка характеризується здатністю образно мислити, застосовувати раніше отримані знання на практиці, знаходити нестандартні рішення, змінювати ракурс погляду, бачити альтернативу тощо; толерантність, емпатійність, духовність (прагнення вплинути на духовний світ інших через мистецтво); виконавська й емоційно-образна мобільність, що проявляється у фрормі швидких емоційних реакцій на різні художньо-образні явища, художньо-творчих ситуацій [6].

На переконання дослідниці, художньо-ментальними процесами виступають формування художнього світогляду, художньої картини світу, художнього мислення, духовної сорери особистості вчителя, орієнтація на етнохудожній сегмент культури, виховання молоді на основі сорормованих художніх цінностей, що охоплюють і відображають сорормованість цінності нації, держави, народу, розвиток емоційної та духовної сфер особистості тощо [6]. 
У просресійній діяльності ментальний досвід $€$ формою фріксації й репрезентації об'єктивного світу, френоменом, який структурує і регулює психічне життя людини в цілому. Художньо-ментальний досвід як феномен набувається для здійснення духовних практик: осмислення, інтелектуальної та емоційної переробки художньої інформації з точки зору іï̈ цінності, смислової сутності, відповідності до культурних традицій, етнічної та регіональної приналежності, що стає основою творчої інтерпретації та практичного застосування отриманих знань під час самоідентифікації та творчої самореалізації в мистецько-педагогічному процесі.

Висновки із цього дослідження і подальші перспективи в цьому напряму. Пріоритетним напрямом розвитку вищої педагогічної освіти останнім часом стало підвищення ії якості. Мета педагогічної освіти стала співвідноситись з формуванням ключових компетентностей у різних галузях, зокрема й підготовки майбутніх учителів хореографії. Серед ключових компетентностей, необхідних майбутнім учителям хореографії для здійснення професійної діяльності, $€$ художньо-ментальний досвід як френомен у підготовці майбутніх учителів хореографії, що дозволяє ссрормувати у свідомості студентів художню модель світу в особливих знаках і формах, котрі впливають на ціннісні орієнтації, а також на поведінку та ставлення до навколишнього середовища.

\section{БІБЛІОГРАФІЧНИЙ СПИСОК:}

1. Авраменко О.В. Сутність і зміст підготовки хореографів до просресійної діяльності. Теорія та методика навчання та виховання : зб. наук. праць. Харків, 2018. Вип. 44. С. 4-16.
2. Бетильмерзаева М.М. Этническая ментальность в системе культуры : автор. дис. канд филлос. наук : 24.00.01. Ростов-на-Дону, 2005. 20 с.

3. Гершунский Б.С. Филососия образования для XXI века. (В поисках практико-ориентированных образовательных концепций). Москва : Изд-во «Совершенство», 1998. 608 с.

4. Пархоменко О.М. Формування балетмейстерських умінь майбутніх учителів хореограсрії в процесі фрахової підготовки : дис. ... канд. пед. наук : 13.00.04. Київ, 2016. 210 с.

5. Реброва О. Формування художньо-ментального досвіду майбутніх учителів музики та хореограсрії в контексті поліпарадигмальної методології. Наукові записки Тернопільського національного педагогічного університету імені Володимира Гнатюка. Серія : Педагогіка. 2013. № 4. С. 18-23.

6. Реброва О.Є. Теоретичне дослідження художньо-ментального досвіду в проекції педагогіки мистецтва : монографрія. Київ : НПУ імені М.П. Драгоманова, 2013. 295 c

7. Сердюк Т.І. Художньо-естетична школа майбутніх учителів хореографрії: формування досвіду : [монографрія]. Донецьк : ЛАНДОН-XXI, 2011. 273 с.

8. Степанюк І.В. Хореографічна освіта як чинник формування національної свідомості. Філософрія освіти. 2011. № 24. Розділ III. С. 118-121.

9. Українська художня культура : навч. посібник. Київ : Либідь, 1996. С. 7.

10. Цяньцянь Лю. Сорормованість художньої грамотності в майбутніх учителів музики та хореограсріï. URL: https://scienceandeducation.pdpu.edu. ua/doc/2009/7_2009/40.pdf.pdf] (дата звернення 12.06.2019)

11. Щолокова О. Категорія духовності у мистецькій освіті: компетентнісний аспект. Естетика і етика педагогічної дії : збірник наук. пр. Київ-Полтава. 2011. C. 127-136. 